\title{
IAMJ
}

INTERNATIONAL

AYURVEDIC

MEDICAL JOURNAL

ISSN: 2320-5091

Impact Factor: 6.719

\section{REVIEW ON HEPATOPROTECTIVE EFFECT OF BERBERIS ARISTATA DC.}

\author{
Paudel Kiran ${ }^{1}$, Ramamurthy Aku², Sharma Gaurav ${ }^{3}$ \\ ${ }^{1}$ MD Scholar, ${ }^{2}$ Professor, ${ }^{3}$ Pharmacologist \\ Postgraduate Department of Dravyaguna \\ National Institute of Ayurveda, Madav Vilas Palace, Amer Road, Jaipur (302002), Rajasthan, India.
}

Corresponding Author: drkiranpaudel@gmail.com

https://doi.org/10.46607/iamj.3109012021

(Published online: January 2021)

Open Access

(C) International Ayurvedic Medical Journal, India 2021

Article Received:22/12/2020 - Peer Reviewed:02/01/2021 - Accepted for Publication:06/01/2021

D) Check for updates

\section{ABSTRACT}

Berberis Aristata DC. belonging to the family Berberidaceae, is a shrub used in the alternative medical systems that is native to Northern Himalaya region, Nepal, India and Pakistan. It is commonly known as "Daruharidra and Chitra". Berberis aristata DC. is used in Ayurvedic Medicinal system from the beginning of this System. It is widely used as a hepatoproctive, tonic, in urinary disorders, skin diseases, diaphoretic, diuretics and treatment of diarrhoea, Jaundice, Syphilis. Natural source of Berberine is Daruharidra which reduces the inflammation of hepatocytes in liver. The study was aimed to analyze its' hepatoprotective effect on the basis of Modern scientific evidence and Classical Ayurveda references. Ayurvedic literature describes Daruharidra plant is mainly used in Kamala, Prameha, Kustha, Netra Roga, Vrana.

Keywords: Berberis Aristata DC., Daruharidra, Hepatoprotective, Jaundice, Anaemia, Liver diseases, Hepatotoxicity, Hepatitis.

\section{INTRODUCTION}

The 'Yakrit' is an important organ of the body correlated with the Liver. The 'Yakrit Vikar' is a group of
Diseases related to the Liver. Charak Samhita gives explanation regarding to the disease Yakritodara or 
Yakrit Vriddhi and Yakritodara is mentioned along Pleehodara which is a type of Udara rog. Acharya Susruta explains regarding Yakritpleeha Utpatti, Pleehodara and Yekritdaalyodar ${ }^{2}$. Chakrapani has commented on description of Yakritodara in Charak Samhita along with Pleehodara and mentioned that there are five types of Pleehadoshas-Vataj, Pittaj, Kaphaj, Sannipataj and Rakta 4 . Pleeha Vriddhi occurs in Vamparshwa and similar characteristic is found in Yakrit which occupies space in Dakshinparshwa ${ }^{1}$. Pleeha-Yakrit Chikitsha is mentioned in Chakradat$t a^{4}$. The disease Yakrit Roga for the first time was introduced by Bhav Mishra in the Bhavprakash. Here, the shoroop of Yakrit is mentioned and said to be Visheshayavyava and it is said to be Sthana of Ranjak pitta. In Bhav Prakash Hetu, Samprapti, Lakshana of Yakrit Vikar resembles to Pleehavikar ${ }^{5}$. The Liver disorders are Jaundice, Gastrointestinal bleeding, Ascites, Hepatic encephalopathy, Acute liver failure, Chronic liver failure ${ }^{8}$. Acharya Charak described for Pandu Roga treated by Katukadya Ghrita, Pandunasak Ghrita, Kamalanasak Swaras, Manduk Vatak, Punarnawa Mandur ${ }^{1}$, In Astanga Hridaya for Udar Roga treatment Hingwadi Kshar is described, For Pandu Roga treatment Mandur Vatak, for Kamala treatment Prayukta Swaras ${ }^{3}$ is described. These mentioned medicinal preparation almost includes $D a$ ruharidra (Berberis aristata DC.) for the treatment of Yakrit Vikar. Daruharidra is scientifically accepted as Berberis aristata DC. and a famous drug for treating liver related diseases as Pandu, Kamala, Udar Roga ${ }^{6}$. Bhavprakash Nighantu, Dhanwantari Nighantu, Priya Nighantu also described this plant for different medicinal values. Berberis aristata DC. found in Himalayan region in 3000-7000 ft. height. The plant has spines on margins of leaves. Fruit appears in rainy season?

- Division- Angiospermae

- Class- Diacotyledones

- Family- Berberidaceae

- Genus- Berberis

- Species- aristata

- Classical name-Daruharidra

- Sanskrit Name-Pitadru, Kaleyak, Haridrav, Pachampacha, Kantakateri, Kamani, Hemakanti,
Daruharidra, Pitadaru, Pitachandana, Karkatakini, Katamkati, Kanchani, Kamavati, Kastharanjani, Kusumbhaka, Krimihara, Darvi, Darunisha, Darupurba, Drabidabi, Nisha, Parjani, Parjanya.

- Vernacular Names- Bengali- Daruharidra; Gujrati- Daruharidra, Daruhlaadur; Hindi- Daruhaldi, Darhald; Marathi- Daruhalad; Oriya- Daruhalidi, Punjabi- Sumalu, Tamil- Gangeti, NepaliChutro.

- English name- Indian berberry, Tree turmeric, Nepal berberry, Opthalmic barberry.

- Habit- It is large deciduous shrub, usually 1.7-3.5 $\mathrm{m}$ in height. The plant has glossy dark green and ovate leaves, stalked flowers and wood, yellowish brown roots with thin covering bark. ${ }^{9,10,11,12}$

- Habitat-Himalayan region, 3-7 thousand $\mathrm{ft}$. height in Nepal, India, Pakistan.

- Parts used- Roots, Stems, Leaves and Fruits.

In Unani system of medicine, Bark of Berberis aristata DC. is known as Darhald. It is frequently prescribed in the treatment of hepatomegaly, hepatitis, splenomegaly ${ }^{13}$.

In Paipalyaad Samhita (Atharvavediya-20/37/7)Darupatra is explained. In Keshav Paddati Decoction of Haridra and Daruharidra is used in Khalitya. In Bamana Purana Daruharidra was found in the name of Peetadaru and Haridru. In Kalpasutra, Daruharid$r a$ is mentioned as a plant and given many synonyms ${ }^{6}$. In Samhita kala, Charak Samhita Daruharidra is mentioned in different contexts synonyms and totally 79 times $^{1}$ and in Sushruta Samhita Daruharidra is described in 38 different contexts ${ }^{2}$. In Astanga Hridaya Daruharidra were explained in 69 different contexts $^{3}$.

In Ayurveda, Daruharidra is distinguished as a Hepatoprotective drug. It is used in Brana, Prameha, Kan$d u$, Bisharpa. It is described in gana as arshoghna, kandughna, lekhaniyamahakasaya in Charak Samhita; haridradi, mustadi and lakshadi in Sushruta Samhita and Sirovirachana in Astanga Hridaya.

Hepatoprotective drugs are those drugs which protect liver from any infections. Daruharidra has been described by various Acharyas for kamala and various 
other diseases. Daruharidra has Ruksha Guna, Tikta, Katu Rasa, Katu Vipaka and Ushna Virya and mainly Lekhana Karma which have main role in the Bahupittakamala i.e. Hepatitis. Daruharidra have berberine chemical constituents which have main role in hepatoprotective activity. other constituents are aromoline, oxyacanthine, oxaberberine and palmatine ${ }^{14}$.

\section{Aim and Objectives}

1. To compile and evaluate the hepatoprotective activities of Berberis aristata DC. in the Modern scientific data and with Ayurvediya properties.

2. To analyze Berberis aristata DC. in the liver related disorders as a hepatoprotective drug.

\section{Material and Methods}

A Bibliographic investigation were done by analyzing Articles, Peer-reviewed paper, Google Scholar, PubMed., Reference books, worldwide accepted scientific databases. The Hepatoprotactive Drugs, Antihepatic Herbal Medicine, Hepatic Diseases, Berberis aristata DC as hepatoprotective drug, Yakritroga, Daruharid$r a$ words were used to search in the Online Databases. Extracted data was analysed to find the applicability of Berberis aristata DC. in Hepatic diseases as Hepatoprotective actions.

\section{Results and Analysis}

Results and Analysis have been conducted in the following ways:

1. Scientific data of BA in relation to Hepatoprotective medicine in modern scientific methods.

2. Ayurveda properties of BA have been analyzed in the reference of Yakritvikaras.

\section{Hepatoprotective Activity:}

1.1 Scientific Data of BA in the reference of Hepatoprotective action:

According to WHO problems related to liver leads to death of estimates about 1.4 millions peoples in the world. Liver diseases are one of the leading causes of illness and death in the society ${ }^{15,16}$. Liver injury caused by different infections, certain drugs, environmental and social factors such as alcoholism, infections, autoimmune disorders ${ }^{17}$ resulting in severe pathological conditions such as hepatitis, Liver cirrhosis, Hepatosis (Non inflammatory diseases) etc ${ }^{18}$. The major agents involved are Hepatitis B, A, C, D, E and
G. Hepatitis B in chronic condition leads to Liver cancer $^{19}$. Transaminase, Alkaline phosphatase, Bilirubin, Triglycerides and Cholesterol are elevated in the liver disease ${ }^{20}$. On the basis of the Biomarkers three major classes of the Hepatotoxicity are as- Hepatocellular injury, Cholestatic injury, Mixed injury ${ }^{21}$. Dried aerial part of BA was investigated in aqueous and methanolic extract and berberine, against CCL4 induced liver damage. The hepatoprotective activity of BA extract in Paracetamol and CCL4 shows protection against liver toxicity and have hepatoprotective action by inhibition of microsomal drug metabolizing enzyme ${ }^{22,23}$. Butanolic extract of BA shows action as hepatoprotective by selective intropic activities ${ }^{24}$. BA leaves and fruits showed hepatoprotection possibly through inhibitory action on hepatic drug metabolizing enzyme $^{31,32}$.

Pre-treatment of animals with berberine which is extract of Berberis aristata DC., $4 \mathrm{mg} / \mathrm{kg}$; orally twice daily for 2 days prevented the acetaminophen or CCL4 induced rise in serum level of alkaline Phosphatase, ALP and aminotransminases, AST and ALT, suggestive of Hepatoprotection. Post-treatment with three successive oral doses of berberine $4 \mathrm{mg} / \mathrm{kg}$ every 6 hrs reduced the hepatic damage induced by acetaminophen, while CCL4-induced hepatotoxicity was not modified, suggesting a selective curative effect against acetaminophen ${ }^{33,34,35}$

\subsection{Effect of BA in Liver cirrhosis:}

Dimethylnitrosamine (DMN) induced liver cirrhosis in rat is established and reproducible and it have a very much similarities with human liver cirrhosis ${ }^{25}$. In vivo study on rat shows that Ethanolic extract of BA (EEBA) and Alcoholic extract of BA (AEBA) treatment orally (daily dose $3000 \mathrm{mg} / \mathrm{kg}$ of body wt. for 4 weeks) improved the survival rate of these rats on day 28 compared to vehicle-treated cirrhotic rats $^{26}$. Invitro study in cell line L02 of bioactive compound (Berberine) of BA in apoptosis induced by $\mathrm{H}_{2} \mathrm{O}_{2}$ chemical shows the mechanisms of protection of hepatocytes from apoptosis by Decrease Caspase-3, decrease PARP, Decrease FasL, Decrease Bim and Increase SIRT1 ${ }^{27 .}$ 


\subsection{Anti-carcinogenic activity:}

Berberine and alkaloid isolated from BA have a property of inhibition significantly carcinogenesis induced by 20 -methylcholanthrene ( $200 \mathrm{microg} / 0.1 \mathrm{~mL} / \mathrm{mouse}$ ) of N-trisodiethylamine (NDEA-0.02\% NDEA in distilled water, $2.5 \mathrm{~mL} /$ animal by gavage, first day a week for 20 weeks) in a dose dependent manner in a small animals. Berberine of dose $(0.5,2.5$ or 5.0 $\mathrm{mg} / \mathrm{kg}$ ) reduces significant level of tumor in animal after an injection of 20-methylcholanthrene and increased their life span compared with the control. Berberine of dose 10,25 or $50 \mathrm{mg} / \mathrm{kg}$ was administered simultaneously with NDEA, the markers of liver injury were reduced significantly compared with animal treated with NDEA only, which resulted in all values being elevated. Methanolic extract of stems of BA is also showing promising results against breast and colon cancer cell lines ${ }^{28,29,30}$.

\subsection{BA as Hepatoprotective drug in Infective Hepatitis:}

Infective Hepatitis is the highly contagious disease that attacks hepatocytes of $\operatorname{liver}^{36}$. Hepatitis 'A' (Known as Infectious Hepatitis) is acute infections of the caused by Hepatitis 'A' Virus (HAV) and RNA Virus. The Route of infection of 'HAV' is fecal-oral route $^{36}$. Symptoms appear 2 to 6 weeks after the initial infection and usually symptoms is less than two months. BA have Berberine, Aromoline, Palmatine, oxyacanthine ${ }^{37}$. The berberine have properties of cholegogue, hepatostimulant and astringent and are useful in treating anorexia, dysentery and hepatitis ${ }^{38}$. BA definitely reduces the duration of symptoms of Hepatitis $^{39}$.

\subsection{Use of Chemical component Berberine of BA in Non-Alcoholic Fatty Liver Disease (NAFLD):}

Berberine is reported to inhibit cholesterol and triglyceride synthesis in human hepatoma cell line (HepG2) cells and primary hepatocytes ${ }^{40,41}$ and treating rat hepatoma H4IIE cells with BBR shows increased glucose consumption in dose dependent manner ${ }^{42}$. In vivo model of animals also confirms BBR's beneficial role in preventing or treating NAFLD. Intraperitoneal injection of BBR compound chemical for
3 weeks has been studied to alleviate hyperlipidemia and fatty liver on obese (ob/ob) and diabetes $(\mathrm{db} / \mathrm{db})$ mice $^{43}$. BBR chemical used In Zucker diabetic fatty liver rats attenuate fatty degeneration ${ }^{44}$ in Hyperlipidemic hamsters with BBR strongly reduces fat storage in liver ${ }^{40}$. As for mice with high fat diet (HFD) induced fatty liver, sixteen weeks BBR supplement could alleviate hepatic steatosis and decrease liver lipid content by $14 \%{ }^{45}$. BBR prevents development of obesity and insulin resistance in HFD-fed rats ${ }^{46}$. BBR has been shown to reduce liver necrosis both in nonalcoholic steatosis and in steatosis due to hepatitis $\mathrm{C}$ infection $^{47,48}$.

\subsection{BA extract in Hepatic Amoebiasis:}

The activity of crude extract formulations of Berberis aristata, Boerhavia diffusa, Tinospora cordifolia, Terminalia chebula and Zingiber officinale was evaluated in experimental amoebic liver abscess in golden hamsters. The formulation had a maximum cure rate of $73 \%$ at a dose of $800 \mathrm{mg} / \mathrm{kg} /$ day in hepatic amoebiasis, reducing the average degree of infection (ADI) to 1.3 as compared to 4.2 for sham-treated controls ${ }^{59}$.

\section{Other activities -}

\subsection{Anti-microbial activity:}

Ethanolic root extract of BA shows antifungal activi$\mathrm{ty}^{53}$. The extract of BA (aqueous, alcoholic and powdered root in distilled water) shows wide range of antibacterial activity against Gram-positive bacteria. The extract was also tested for antibacterial activity against Gram-negative bacteria; the antibacterial activity was limited against E.coli, S. typhimurium, S. dysenteriae type 1 and $V$. cholera, the best activity being against $V$. cholera. The Gram-negative bacteria reported here as susceptible to the extract of BA are important human pathogens responsible for causing diarrhea and dysentery ${ }^{54,55}$. Berberine, administered orally, resulted in satisfactory parasitological cure, comparable to that obtained with other established antigiardial drugs ${ }^{56}$.

\subsection{Antidepressant activity:}

Berberine exerted anti-depressant like effect in various behavioral paradigms of despair possibility by modulating brain biogenic amines. Further, nitric oxide pathway or sigma receptors are involved in mediating its antidepressant like activity in mouse forced 
swim test ${ }^{57}$. Berberine activity on the central nervous system work as the involvement of L-arginine-nitric oxide (NO)-cyclic guanosine monophosphate (cGMP) signaling pathway in the antidepressant action of berberine chloride was investigated ${ }^{58}$.

\subsection{Antidiabetic activity:}

Dried and Powdered root extracted with water and methanol and crude extract was administered to normal and alloxan induced diabetic albino rat. The result shows that BA roots contain potent and orally effective antidiabetic component which either triggers the formation of insulin or shows insulin like effect ${ }^{49}$. Antidiabetic activity was screened in albino wistar rat by inducing diabetes by alloxan ${ }^{50}$ and streptozocin ${ }^{51}$. Diabetic rats were treated with ethanolic extract of BA. The results conclude that ethanolic extract possess antidiabetic activity ${ }^{50}$. Berberine may be associated with promoting regeneration and functional recovery of $\beta$-cells ${ }^{31,52}$.

Indirect Pharmacological activities influencing Hepatoprotective activity of BA:

In Gall bladder disorders, Uterine disorders, Fever, Periodic neuralgia and menorrhagia, Ulcer healing, Enlargement of spleen and in Blood purification BA shows significant effect ${ }^{60}$.

\section{Chemical Composition:}

BA contains Berberine (2.23\%), Oxyberberine, Berbamine, Armoline, Karachine, Palmatine, Oxycan- thine and Taxilamine. It also contains Protoberberine and Bisisoquinoline type of Alkaloids. Root contains Alkaloids like Berbamine, Berberine, Oxycanthine, Epiberberine, Palmatine, Dehydrocaroline, Jatrorhizine and Coumbamine , $^{5,8,38}$

\section{Analysis of Ayurvediya properties of BA:}

Ayurveda is that type of Medical system which deals the body in Holistic approach. In Ayurveda diseases are classified according to different aspects. According to Dosha there are two types as Samanyaja and Nanatmaja; Three types as Shakhagat, Marmastisandhigat and Kosthagat; Due to vitiation of Rakta Dhatu Kamala, Plihavriddhi, Raktapitta, Pandu are manifested. Pandu and Kamala have 5 and 2 types respectively. According to types Pandu have different clinical signs and symptoms. Generally appearing signs and symptoms are Indigestion, Fatigue, Tiredness, Swelling on body parts, Fever etc. Kamala have symptoms of Yellowish coloration of eye, skin, oral cavity, Nail, urine and faeces, Nausea and vomiting, Loss of appetite, Burning sensation of body, Extreme weakness. Daruharidra is mainly explained in Ayurveda in Netraroga, Kamala, Pandu Roga and various Yakrit Vikaras ${ }^{1}$.

Classifications of Daruharidra in Ayurveda: Daruharidra is important medicinal plant in Ayurveda and have classifications on various varga as in table 1.

Table 1: Classifications of Daruharidra in Ayurveda:

\begin{tabular}{|c|c|c|}
\hline Name of the text & $\begin{array}{l}\text { Classification un- } \\
\text { der Varga (group- } \\
\text { ing) }\end{array}$ & References \\
\hline Charak Samhita & $\begin{array}{l}\text { Arshoghna, } \\
\text { Kandughna, Lek- } \\
\text { hananiya }\end{array}$ & $\begin{array}{l}\text { Sutra-4/3,12,14;5,60; Viman-7/17;8/143,150 } \\
\text { Chikitsha-6/27,28; 7/45, 60, 83, 90, 93, 96, 102, 113, 119, 135.139; 8/136; } \\
\text { 14/160, 186,196, 221, 231, 234;15/135,137;16/53, 62, 72, 96; 26/52, 187, } \\
\text { 190, 196, 197, 199, 200, 236, 241. }\end{array}$ \\
\hline Sushruta Samhita & $\begin{array}{l}\text { Haridradi, Mustadi, } \\
\text { Lakshadi }\end{array}$ & Sutra-46/432; 38/27, 54; Chikitsha-2/69;5/42; 9/35; 18/18; 19/40; 11/8 \\
\hline Astanga Hridaya & $\begin{array}{l}\text { Arshoghna, Sirovi- } \\
\text { rachana }\end{array}$ & $\begin{array}{l}\text { Sutra-15/4;20-38;22/19; Saarir-1/62; Chikitsha-8/103, 131; 9/58, 90; 10/35; } \\
\text { 11/8; 12/6,7; 16-16, 43; 26/26; 37/73 }\end{array}$ \\
\hline $\begin{array}{l}\text { Dhanvantari } \\
\text { Nighantu }\end{array}$ & Guduchhadivarga & $56-59$ \\
\hline Madhav Dravyaguna & Bibidhausadhivarga & 105 \\
\hline
\end{tabular}




\begin{tabular}{|l|l|l|}
\hline Kaiyadev Nighantu & Aushadivarga & $1116-1117$ \\
\hline Raj Nighantu & Pipalyadivarga & 175 \\
\hline $\begin{array}{l}\text { Bhavprakash } \\
\text { Nighantu }\end{array}$ & Haridradivarga & $201-205$ \\
\hline Priya Nighantu & Satapuspadivarga & $200-202$ \\
\hline Nighantu Adarsha & $\begin{array}{l}\text { Daruharidradivar- } \\
\text { ga }\end{array}$ & $6^{\text {th }}$ Varga \\
\hline Dravyagunavigyanan & Arshoghnadivarga & 537 \\
\hline
\end{tabular}

\section{Formulations of Daruharidra:}

In Ayurveda yakrit Vikaras are generally classified as in Abhighat (Injury to Liver), Bidradhi (Liver abscess), Yakrtidalyudar, Granthi (Liver cyst), Yakritarvuda (Hepatic tumors)2 ${ }^{2}$ Daruharidra in Ayurveda have main roles in the treatment of these Vikaras.
Formulations related to these Vikaras are Kiratatiktadichurna, Kanakarista etc. are given in Table 2. These medicines are given for Pandu, Kamala and other types of Yakritvikaras having various signs and symptoms.

Table 2: Common Formulations of Daruharidra used for Yakritvikara:

\begin{tabular}{|c|c|c|}
\hline Name of text & Formulations & References \\
\hline \multirow[t]{5}{*}{ Charak Samhita } & Kanakarista & Cha.chi.14/160 \\
\hline & Kiratatiktadyachurna & Cha.chi.15/137 \\
\hline & Punarnavamanduravataka & Cha.chi. $16 / 93$ \\
\hline & Dravadileha & cha.chi.16/97 \\
\hline & Vyoshadyaghrita & cha.chi.16/119 \\
\hline \multirow[t]{3}{*}{ Chakradatta } & Darvadileha; Vyoshadyaghrita & $8 / 28 ; 8 / 56$ \\
\hline & Trausanadyamandura & $8 / 34$ \\
\hline & Punarnavamandura & $8 / 42$ \\
\hline Sarangadhar Samhita & Triphaladiswaras & Sa.ma.1/9 \\
\hline \multirow{2}{*}{ Bhavprakash Nighantu } & Triushanadimandura & Bha.ma.chi.8/50 \\
\hline & Astadashangalauha & Bha.ma.chi.8/55 \\
\hline
\end{tabular}

Pharmacodynamic Properties of Daruharidra in Ayurveda:

These seven constituents of Dravyaguna are Dravya (Drug), Rasa (Taste), Guna (Property), Virya (Potency), Vipak (Drug metabolism), Prabhava (Nonspecific activity) and Karma (Pharmacological action). Daruharidra is roghagna, Oudbhidam (Plant origin), Vanaspatya (Plant possess both flower and fruits).

On the basis of Padartha of Dravyaguna, Daruharid$r a$ have following Properties as described by different
Acharyas given in Table 3. Rasa is that property which is perceived through the taste-buds. Guna is the property which will have inherent relation with the dravya but remain inactive. Vipaka is the property of a drug which is responsible for the change in original taste on exposure to GIT enzymes and responsible for the final form of the drug inside the body. Virya is the property by which the drug produces the therapeutic effect. Karma is the inseparable reason for the association (Samyoga) and dissociation (Vibhaga) of a drug in exhibiting its pharmacological action ${ }^{61}$. 
Table 3: Rasapanchak of BA:

\begin{tabular}{|l|l|l|l|l|l|l|}
\hline Name of text & Guna & Rasa & Virya & Vipak & Doshakarma & References \\
\hline Dh. Ni. & Ruksha & Tikta & Ushna & - & - & Guduchayadivarga:56-58 \\
\hline Ni. Ad. & Ruksha & Tikta & Ushna & Katu & Kaphapittahara & Daruharidradivarga \\
\hline Mad. D.G. & Ruksha, Laghu & Tikta, Katu & - & - & Kaphanashani & Bividhausadivarga: 105 \\
\hline D.G. Vigyana & Laghu, Ruksha & Tikta, Kashaya & Ushna & Katu & Kaphapittanasak & Arshognadivarga \\
\hline Pri. Ni. & - & Tikta & Ushna & - & Kaphapittahara & Satapuspadi: $172-174$ \\
\hline Bhav. Ni. & Ruksha & Katu, Tikta & Ushna & katu & Kaphapittanashana & Hritakyadivarga: 201-205 \\
\hline ka. Ni. & Ruksha & Tikta, Katu & Ushna & Katu & Kaphapittanashana & Aushadivarga:1116-1117 \\
\hline
\end{tabular}

(Dh.Ni-Dhanvantarinighantu, Ni. Ad.-Nighantu Adarsha, Mad. D. G-Madhav Dravya Guna, D. G. vigyanan-Dravyagunavigyanan, Pri. Ni-Priya Nighantu, Bhav. Ni-Bhavprakash Nighantu, Ka. NiKayadev Nighantu)

Laghuguna is the quality which results the lightness. It acts as Kaphahara and Vatavardhaka. Rukshaguna is the property which is responsible for dryness or responsible of absorption of moisture. It subsides the kapha and aggravates vata. Rukshaguna results in sthambhana, soshana, Rukshana, Avrishya actions ${ }^{5,3,2}$.
The Pharmacodynamics properties of Daruharidra are summarized as follow ${ }^{6}$ :

Rasa (Taste)- Katu, Tikta (Bitter)

Guna (properties)- Laghu (Light), Ruksha (Dryness)

Virya (Potency)- Ushna

Vipak(Metabolic transformation)- Katu

Dosha karma (Actions)- Kaphapittahara

On the basis of these properties of Daruharidra, its action are tabulated in Table 4. These are Vrananasaka, Pramehahara, Kanduhara, Pandunasana, Kamalahara etc.

Table 4: Karma (actions) of Daruharidra according to Ayurveda texts

\begin{tabular}{|c|c|c|c|c|c|c|c|c|c|c|}
\hline Karma & Ma.Ni. & $\begin{array}{l}\text { D.G. } \\
\text { Vigyanana }\end{array}$ & $\begin{array}{l}\text { Ka. } \\
N i .\end{array}$ & Ma.Bi.Ni. & $\begin{array}{l}\text { Dh. } \\
\text { Ni. }\end{array}$ & $\begin{array}{l}\text { Ni. } \\
\text { Ad. }\end{array}$ & $\begin{array}{l}\text { Pri. } \\
\text { Ni. }\end{array}$ & Bhav.Ni. & $\begin{array}{l}\text { Mad. } \\
\text { D.G }\end{array}$ & So.Ni. \\
\hline Vrana & + & - & + & - & + & + & + & + & + & + \\
\hline Kandu & - & + & - & - & - & + & - & - & + & - \\
\hline Tvakrog & - & + & - & - & - & - & - & + & - & - \\
\hline Mukharog & + & + & + & - & - & + & + & + & - & - \\
\hline Varnya & - & - & + & - & - & - & + & + & - & - \\
\hline Pandu & + & + & + & - & - & - & + & + & - & - \\
\hline Yakritrog & - & + & - & - & + & - & + & - & - & - \\
\hline
\end{tabular}

(Ma.Ni.-Madhanpal Nighantu, D.G.VigyananDravyagunavigyanan, Ka.Ni.-Kaiyadev Nighantu, Ma.Bi.Ni-Madan Binod Nighantu, Dh.Ni-Dhanvantari Nighantu, Ni.Ad- Nighantu Adarsha, Pri.Ni-Priya Nighantu, Bhav. Ni-Bhavpraksah Nighantu, Mad.D.GMadhav Dravyaguna, So.Ni-SodhalNighatu)

\section{DISCUSSION}

Daruharidra have Rasa: Katu, Tikta; Guna: Laghu, Ruksha; Virya: Ushna and Vipak: Katu and is rich in content of Berberine. It alleviates Kapha and Pittadoshas $^{38}$. 
Due to Berberine as chemical constituent and Tikta rasa of Daruharidra, it reduces the excretion of excessive formation of bile pigments. Due to this factor it reduces the level of serum enzymes in the blood and decreases the inflammation in liver cells. Tikta rasa of Daruharidra have functions as Raktasodhana, Tvaka, Mamsaprasadaka and Yakrituttejak. These properties of Daruharidra acts as a drug in Kamala, Pandu, Yakritvikarhara ${ }^{1}$. Meanwhile, Ushna Virya helps to reach all the body parts due to its Agneya nature and mobility nature and with Ushna Virya; Laghu, Rukhsha Guna helps to pacify Kaphadosha. All these properties of Daruharidra shows antioxidative, antiinflammatory, anticancer, Hepatoprotective, Immunomodulatory and also useful in treating anorexia, dysentery, Gallbladder problems, Hepatitis ${ }^{38}$.

\section{CONCLUSION}

Berberis aristata DC has been tested by the researchers for its various effects of the body. In Ayurveda, it is been used in many diseases as a combined ingredient and single drug of medicine. Daruharidra is used as a medicine since Veda, Upanishad and Samhita period. Due to its important properties, Daruharidra shows hepatoprotective action against various Liver related problems. Experimental and Clinical studies show that it shows Hepatoprotective, Antioxidative and in Ayurveda Netraroghara, Mukharognasaka, Yakritvikarnasaka and Plihavikarhara properties.

\section{REFERENCES}

1. Agnivesha. Charak Samhita. Vaidya Yadavji Trikamji Acharya editor. Edition reprint Chaukhamba Surbharati Prakashan: Varanasi; Edition 2017.

2. Sushruta, Sushruta Samhita. Vaidya Jadavji Trikamji Acharya and by Narayan Ram Acharya 'Kavyatirtha' editor. Edition reprint Chaukhamba Surbharati Prakashan: Varanasi; Edition 2018.

3. Vagbhata. Astanga Hridaya, Pt. Hari Sadasiva Sastri Paradakara Bhisagacharya editor, Edition reprint Chaukhamba Surbharati Prakashan: Varanasi, Edition 2017.

4. Chakrapanidatta. Chakradatta. Pt. Brahmashankar Mishra Editor; Edition reprint Chowkhamba Sanskrit
Series Office: Varanasi, $7^{\text {th }}$ Edition 2012. Chapter 38, p310-315.

5. Chunekar KC. Bhavprakash. Chowkhamba Sanskrit Bhawan: Varanasi. Madhyakhandey, Chikitsha Prakaran, Chapter 33, p355, 356, 357.

6. Sharma PV. Dravyaguna Vijnana, Vol. II, IV (Vegetable Drugs), Chaukhambha Bharati Academy, Varanasi, Edition 2019. Chapter 6, p537-539.

7. Kritikar RK, Basu DB and I.C.S. Blatter E, Caius FJ, Mhaskar KS Editor. Indian Medicinal Plants: Vol 1, $2^{\text {nd }}$ Edition, Bishen Singh Mahendra Pal Singh: Dehre Dun, 1993.

8. Tripathi KD. Essentials of Medicinal pharmacology: 4th edition. New Delhi: Jaypee Brothers Medical Publishers (P) Ltd;2001.

9. Ali M, Malik A, Sharma KR. Vegetative propagation of Berberis aristata DC. An endangered Himalayan shrub. J Med Plants Res 2008; 2:374-7.

10. Annonymous. The Wealth of India Berberis Linn. (Berberiadaceae), In: Amvastha SP, editor. New Delhi: Publication and information Directorate, CSIR, 1988. p114-8.

11. Srivastava S, Rawat A. Quality evaluation of ayurvedic crude drug Daruharidra, its allied species and commercial samples from herbal drug markets of india. Evid Based Complement Alternat Med 2013; 2013:114.

12. Wallis TE. Practical Pharmacognosy. London: J and A Churchill Ltd. 1946. p185-6.

13. Ghani N, Khazeenat-ul-Advia. Matba Munshi Nawal Kishore, Lucknow, Vol.2, 1st Edition. pp.530-531 (b,a), 1921.

14. Annonymous: The Wealth of India. In: Ambustha SP Editor: New Delhi: vol. 2B. Publication and Information Directorate, CSIR;1988. pp.188.

15. Yang J, Li Y, Wang F, Wu C. Hepatoprotective effects of apple polyphenols on CCL4-induced acute liver damage in Mice. J Agric Food Chem. 2010;58(10):6525-31.

16. Guyton H. Textbook of Medicinal Physiology, 10th edition, Philadelphia, The Curtis Center Saunders. 2000:798-801.

17. Pushpangadan P, Role of Traditional Medicine in Primary Health Care. In: Iyengar PK, Damodaran VK, Pushpangadan P Editors. Science for Health. Published by State Committee on Science, Technology and environment, Govt. of Kerala, 1995.

18. Aszalos A, Editor. Antitumor Compounds of Natural Origin. Boca Raton, CRC Press, 1982. 
19. http://www.cancer.ca/en/cancer-information/diagnosisand-treatment/chemotherapy-and-other drug therapies/chemotherapy/sideeffects-of-chemotherapy/liverdamage-and-chemotherapy/?region $=$ on.

20. Subramaniam S, Khan HBH, Elumalai N, Lakshmi SYS. Hepatoprotective effects of ethanolic extract of whole plant of Andrographis paniculata against CCL4 induced hepatotoxicity in rats. Comp Clin Path. 2015; 24:1-7.

21. Navarro VJ, Senior JR. Drug-related hepatotoxicity. N Engl J Med. 2006; 354:731-9.

22. Gilani AH, Janbaz KH, Preventive and curative effects of Berberis aristata fruit extract on paracetamol and CCL4 induced hepatotoxicity. Phytotherapy Res. 1995; 9:489-94.

23. Janbaz KH, Gilani AH. Studies on preventive and curative effects of berberine on chemical-induced hepatotoxicity in rodents. Fitoterapiz. 2000; 71:25-33.

24. Gilani AH, Janbaz KH, Aziz N, Herzig MJU, Kazmi MM, Choudhary MI, Herzig JW. Possible mechanism of selective intropic activities of the n-butanolic fraction from Berberis aristata fruit-distinguishing hype from hope. General Pharmacology. 1999 Nov; 33(5):407-414.

25. Huang $\mathrm{CH}$, Horng LY, Chenc CF, Wu RT. Chinese herb Radix Polygonimultiflori as a therapeutic drug for liver cirrhosis in mice. Journal of Ehtnopharmacology. 2007;199-207.

26. Prashant V. Ajmire et al., Effect of Berberis aristata DC. Against Dimethylnitrosaine Induced Liver Cirrhosis in Rat model. Research article ISSN 0974-6943, www.jpronline.info, 2011.

27. X Zhu, X Guo, G Mao et al., Hepatoprotection of berberine against hydrogenperoxide-induced apoptosis by upregulation of sirtuin, Phytotherapy Research. 2013:27(3):417-421.

28. Chunekar KC. Bhavprakasha Nighantu. Pandey GS Editor. Edition reprint. Varanasi: Chaukhambhavisvabharati.2018.

29. Mazumder PM, Das Saumya, Das Sanjita, Das MK, Basu SP. Cytotoxic activity of Methanolic extract of Berberis aristata DC. on colon cancer. Global J Pharmacology. 2009,3(3):137-140.

30. Mazumder PM, Das Saumya, Das Sanjita, Das MK. Cytotoxic activity of mehtanolic extract of Berberis arisatata DC and Hemidesmus indicus R.Br. on MCF7 cell line. J current Pharmaceutical Research. 2010:01:12-15.
31. Singhal GD, Sharma KR, ophthalmic and otothinolarangological considerations in ancient Indian surgery. Allahabad: Singhal Publications, 1976:13-23.

32. Shastri AD,Sushrutasamhita.Edition reprint.Varanasi: Chaukhamba Oreintalia. 1980.

33. Rabbani GH et al., Randomized control trial of Berberine sulfate therapy for Diarrhoea due to enterotoxigenic E. coli and Vibrio cholera. Journal of Infectious Diseases. 1987;155(5):979-984.

34. Kaneda $\mathrm{Y}$ et al., In vitro effects of berberine sulphate on the growth and structure of Enatanoeba histolytica, Giardia lamblia and Trichomonals vaginalis. Annals of Tropical Medicine and Parasitology. 1991;85(4);417425.

35. Chang HM and But PPH editor, Pharmacology and Applications of Chinese Materica Medica, Vol. 2, 1986 world scientific, Singapore.

36. Anonymous. The Ayurvedic Pharmacopia of India. $7^{\text {th }}$ Edition. New Delhi: Ministry of Health and Family Welfare, Government of India, Department of Indian Medicine and Homeopathy; 2013:pp594.

37. Dr. Paranjpe Prakash, Indian Medicinal Plants. 1 Edition. 2001:pp66.

38. Anonymous. The Ayurvedic Pharmacopia of India. $1^{\text {st }}$ Edition, Part 1 ${ }^{\text {st }}$, Vol. 3. New Delhi: Ministry of Health and Family Welfare, Government of India, Department of Indian Medicine and Homeopathy; 2001.

39. Ramteke AD, Aiyer RB, Gandhi SP, Hadole SP. Phytochemical study of Daruharidra (Berberis aristata DC.) and its Hepatoprotective efficacy in Infective Hepatitis. Journal of Pharmaceutical and Scientific Innovation. www.jpsionline.com, research article, Published by Moksha Publishing House. website: www.mokshaph.com, DOI: 10.7897/22774572.02693,2013.

40. Brusq JM, Ancellin N, Grondin P et al., Inhibition of lipid synthesis through activation of AMP kinase: an additional mechanism for the hypolipidemic effects of berberine. Journal of Lipid Research.2006:47(6);12811288.

41. Ge Y, Zhang Y, Li R, Chen W, Li Y and Chen G. Berberine regulated Gck, G6pc, Pck1 and srebp-1c expression and activated. International Journal of Biological Sciences. 2011:7(5);673-684.

42. Yin J, Gao Z, Liu D, Liu Z and Ye J. Berberine improves glucose metabolism through induction of glycosis. American Journal of Physiology. 2008:294(1); ppE148-E156. 
43. Kim WS, Lee YS, Cha SH et al., "Berberine improves lipid dysregulation in obesity by controlling central and peripheral AMPK activity, 'American Journal of Physiology, Vol. 296, no.4, pp. E812-E819, 2009.

44. Zhao HL, Sui Y, Qiuo CF et al., Sustained antidiabetic effects of berberine-containing Chinese herbal medicine through regulation of hepatic gene expression. Diabetes: 2012:61(4);pp.933-943.

45. Chang X, Yan H, Fei J et al., Berberine reduces methylation of the MTTP promoter and alleviates fatty liver induced by a high-fat diet in rats. Journal of Research. 2010:51(9);pp2504-2515.

46. Zhang X, Zhao Y, Zhang M et al., Structural changes of gut microboita during berberine-mediated prevention of obesity and insulin resistance in high-fat dietfed rats. PLoS ONE. 2012:7(8), Article ID e4259.

47. Zhang BJ, Xu D, Gou Y, Ping J, Chen LB andWang H. Protection by and anti-oxidant mechanism of berberine against rat liver fibrosis induced by multiple hepatotoxic factors. 2008:35(3), pp303-309.

48. Marazzi G, Caccitotti L, Pelliccia F et al., Long-term effects of nutraceuticals (Berberine, red yeast rice, policosanol) in elderly hypercholesterolemia patients. Advances in therapy. 2011:28, (12); pp1105-1113.

49. Akhtar MS, Sajid MS, Ahmad M. Hypoglycemic effect of Berberis aristata root, its aqueous and methanolic extract in normal and alloxan induced diabetic rabbits. Pharmacology online (Italy). 2008; 2:845-856.

50. Semwal BC, Gupta J, Singh S, Kumar Y, Giri M. Antihyperglycemic activity of root of Berberis atistata DC. in alloxan induced diabetic rat. Int. J of green pharmacy. 2009 Jul-Sept; 259-63.

51. Ahamad R, Srivastava SP, Maurya R, Rajendran SM, Arya KR and Srivastava AK. Mild Antihyperglycemic activity in Eclipta alba, Berberis aristata, Betula utilis, Cedrusdoedara, Myristicafragrans and Terminalia chebula. Ind $\mathrm{J}$ of Science and Technology. 2008 oct;1(5):1-6.

52. Yanxia N. Therapeutic effect of berberine on sixty patients with non-insulin dependent diabetes mellitus and experimental research. Chinese Journal of Integrated Traditional and Western Medicine. 1995;1(2):91-95.

53. Sharma RS, Mishra V, Singha R, Setha N and Babua CR. Antifungal activity of some Himalayan medicinal plants and cultivated ornamental species. Fitoterapia. 2008 December;79(7-8):589-91.

54. Shahid M, Rahim T, Shahzad A, Tajuddin, Latif A, Fatma T, Rashid M, Raza Adil and Mustafa S. Ethnobotanical studies on Berberis aristata DC. root extracts.
African J of Biotechnology. 2009 February 18;8(4):556-63.

55. Bradely SR and Froehlich JL. Berberine inhibits intestinal secretory Response of Vibrio cholera and Escherichia coli Enterotoxins. Infection immunity. 1982 Feb;35(2):471-75.

56. Gupta Suraj. Use of Berberine in Treatment of Giardiasis. Am J Dis Child. 1975;129(7):866.

57. Sabnis M. Chemistry and Pharmacology of Ayurvedic medicinal plants. Varanasi: Chaukhambha Surabharati Prakashan. 2006:23-35.

58. Kulkarni SK, Ashish D. Possible involvement of Larginine nitric oxide (NO)-cyclic guanosine monophosphate (cGMP) signaling pathway in the antidepressant activity of berberie chloride. Euporean J of Pharmcology. 2007 August'13; 569(1-2):77-83.

59. Anonymous. The Wealth of India-Raw materials. Council of Scientific and Industrial Research (CSIR) New Delhi: 1988.

60. Mazunder PM, Das S, Das S, Das MK. PhytoPharmacology of Berberis aristata DC: A review. Journal of Drug Delivery \& Therapeutics. 2011;1(2):46-50. online at http://jddtonline.info, december 2011.

61. Shastri JLN. Dravyagunavijnana (Fundamental Principles of Pharmacotherapeutics in Ayurveda): Edition reprint. Chaukhambhaorientalia, Varanasi; 2017.

\author{
ABBREVIATIONS \\ ALP- Alkaline phosphatase \\ ALT- Alanine Aminotransferase \\ AST- Aspartate Aminotransferase \\ BA- Berberis aristata DC \\ BIM- Bcl-2-like 11 \\ CCL4- Carcon tetrachloride. \\ FasL- Fas Ligand \\ PARP- Poly [ADP-ribose] polymerase
}

\section{Source of Support: Nil Conflict of Interest: None Declared}

How to cite this URL: Paudel Kiran et al: Review On Hepatoprotective Effect Of Berberis aristata DC.. International Ayurvedic Medical Journal \{online\} 2021 \{cited January, 2021\} Available from: http://www.iamj.in/posts/images/upload/190_199.pdf 